\title{
Effect of Rice Straw and Husk Biochar on Vegetative Growth and Yield Attributes of Oryza sativa L
}

\author{
Singanayagam Thavanesan ${ }^{1 *}$, Thayamini H. Seran ${ }^{2}$ \\ ${ }^{1}$ Department of Crop Science, Faculty of Agriculture, Eastern University, Chenkalady, Sri Lanka \\ ${ }^{2}$ Department of Crop Science, Faculty of Agriculture, Eastern University, Chenkalady, Sri Lanka
}

\begin{abstract}
A research was conducted to evaluate the growth and yield of rice as influenced by rich straw and husk biochar along with chemical fertilizer. The experiment was done with six treatments. T1- recommended chemical fertilizer, T2- Rice straw (1.0 t/ha), T3-Rice husk biochar (1.0 t/ha), T4-Rice straw (0.5 t/ha) + Rice husk biochar (0.5 t/ha), T5-Rice straw (1.0 t/ha) + Rice husk biochar ( $0.5 \mathrm{t} / \mathrm{ha}$ ) and T6-Rice straw (1.0 t/ha) + Rice husk biochar (1.0 t/ha). Recommended chemical fertilizer was incorporated to all the treatments. During the vegetative periods, the growth parameters were recorded and finally yield analysis was done. Rice plants treated in rice straw $(1.0 \mathrm{t} / \mathrm{ha})$ and husk biochar $(1.0 \mathrm{t} / \mathrm{ha})$ along with chemical fertilizer had significantly $(P<0.05)$ higher mean values of leaf area $\left(185.93 \mathrm{~cm}^{2}\right)$, number of tillers (4.0), number of roots per plant (105.33) and also dry weights of shoots $(5.15 \mathrm{~g})$ and roots $(4.27 \mathrm{~g})$ per plant when comparing chemical fertilizer alone. Average number of grains (187.67), number of filled grains (170.33) and filled grain weight per panicle $(3.142 \mathrm{~g})$ was also considerably increased in rice straw (1.0 t/ha) and husk biochar (1.0 t/ha) treatment followed by husk biochar $(1.0 \mathrm{t} / \mathrm{ha})$ treatment than those in the control. There were no significant difference $(P>0.05)$ in 100 seed weight between them. Hence, it can be concluded that addition of rice straw (1.0 t/ha) and husk biochar (1.0 t/ha) along with chemical fertilizer to rice field is feasible to increase the grain yield under local conditions.
\end{abstract}

Key words: Biochar, Rice straw, Rice husk, Rice, Seed weight

\section{INTRODUCTION}

Rice (Oryza sataiva L.) is the staple food for millions people in Asia. Per capita rice consumption is around $100 \mathrm{~kg}$ per year (Somaratne, 2010). In rice cultivation, fertilizer application is an essential practice to obtain potential yield therefore effective way of fertilizer application is an important (Gamage et al., 2012) to maximize the crop production. But the excess use of chemical fertilizer causes under ground water pollution and destroys soil biota (Somaratne, 2010). Organic fertilizers are good source of plants nutrients which are essential for improvement of soil fertility and crop yield (Oladipo et al., 2005).

In Sri Lanka, rice straw and husk is available as waste annually which can be utilized to improve soil. Paddy straw is an obtainable in large quantity. It has high $\mathrm{C}: \mathrm{N}$ ratio therefore can be used with other organic materials to improve soil water retention and nutrients. Rice husk can also be used as organic material in rice cultivation to reduce environmental problem. The partially burned rice husk (husk biochar) enhances the water holding capacity (Milla et al., 2013) and increases available potassium and magnesium (Gaskin et al., 2010). This experiment was carried to study the effect of rice straw and husk biochar along with inorganic fertilizers on vegetative growth and panicle performance of rice.

\section{MATERIALS AND METHODS}

The experiment was done in 2014-2015 at the Agricultural Research Station, Sammanthurai in Eastern region of Sri Lanka. The soil type is non-calcic brown soil and the Latitude between $7^{0} 22 \mathrm{~N}$ and 
Longitude $81^{0} 48 \mathrm{E}$. The mean temperature is $30^{\circ} \mathrm{C}$ and annual rain fall is $1400 \mathrm{~mm}$.

Rice variety used in this study was At 307 which is a high yielding variety and recommended for cultivation in island wide. It was laid out in RCBD with three replications. The treatments were as follows:

T1 - Chemical fertilizers only

$\mathrm{T} 2-1.0 \mathrm{t} / \mathrm{ha}$ rice straw + chemical fertilizer

$\mathrm{T} 3$ - $1.0 \mathrm{t} / \mathrm{ha}$ rice husk biochar $(\mathrm{RHB})+$ chemical fertilizers

$\mathrm{T} 4-0.5 \mathrm{t} / \mathrm{ha}$ rice straw $+0.5 \mathrm{t} / \mathrm{ha} \mathrm{RHB}+$ chemical fertilizers

T5 - $1.0 \mathrm{t} / \mathrm{ha}$ rice straw $+0.5 \mathrm{t} / \mathrm{ha} \mathrm{RHB}+$ chemical fertilizers

T6 - $1.0 \mathrm{t} / \mathrm{ha}$ rice straw + $1.0 \mathrm{t} / \mathrm{ha} \mathrm{RHB}+$ chemical fertilizers

The size of plots was $1.5 \mathrm{~m}$ x1.5 m. Decayed rice straw and husk biochar were incorporated with soil before one month of seeding for decaying. Rice variety, At 307 was used in this experiment and required seed rate of rice per plot is $35 \mathrm{~g}$. Triple super phosphate $(55 \mathrm{~kg} / \mathrm{ha})$ and zinc sulphate $(5$ $\mathrm{kg} / \mathrm{ha}$ ) were applied prior to sowing. The recommended fertilizer mixture containing $225 \mathrm{~kg} / \mathrm{ha}$ urea and $60 \mathrm{~kg} / \mathrm{ha}$ Muriate of potash was applied after sowing.

All agronomic practices were carried out as recommended by the Department of Agriculture. Growth parameters were taken at 15 days interval after sowing upto 60 days. Each parameter was recorded in randomly selected plants. Samples were placed in oven at $105{ }^{\circ} \mathrm{C}$ to record dry weight of shoot and root. In each treatment, leaf area was measured by portable leaf area meter (L-1 $3000 \mathrm{c}$ ).

Data were analyzed using SAS. Tukey's test was done at $5 \%$ significant level to compare the difference among treatment mean values.

\section{RESULTS AND DISCUSSION}

\section{Leaf area}

There was significant difference in Leaf area among the treatments at 45 and 60 days after planting (DAP). Statistical analysis showed that there were no significant differences $(\mathrm{P}>0.05)$ on average leaf area at 15 and 30 DAP (Table 1). At 60 DAP, treatment T1 had significantly $(\mathrm{P}<0.05)$ lower value in leaf area than other treatments. Agusalim et al. (2010) revealed that addition of rice husk biochar increased the number of rice tillers compared to untreated soil. It correlated with number of leaves. The higher leaf number attributes to higher leaf area. The maximum leaf number of was recorded in $\mathrm{T} 6$ followed by in $\mathrm{T} 3$.

\section{Number of tillers}

The results showed that there were significant variations $(\mathrm{P}<0.05)$ in mean number of tillers among the treatments at 45 and 60 DAP (Table 2). Higher number of tillers was recorded in T6 than the other treatments except T3. Mean number of tillers ranged from 2.8 to 4.0. (Gamage et al., 2012) showed that incorporation of rice husk charcoal to the rice field improved soil fertility to give more yield of rice.

\section{Number of roots}

The result showed that the number of roots was remarkably differed $(\mathrm{P}<0.05)$ among the treatments (Table 3). No significant difference in number of roots was recorded among the treatments at 15 DAP thereafter significant differences were observed.

At 30 DAP, maximum mean number (23.16) of root was recorded in T6 followed by 22.83 in $\mathrm{T} 3$ and $21.83 \mathrm{~cm}$ in $\mathrm{T} 2$ while minimum number of root of 18.33 was recorded in $\mathrm{T} 1$. After 15 DAP, there was significant variation $(\mathrm{P}<0.05)$ on number of roots between the treatments T1 and T6. After 30 
DAP, number of roots was high in RHB treated soil compared with untreated soil. At 60 DAP, the highest mean number of roots (105.33) was recorded in T6. It may be due to combined application of rice straw and husk biochar which improves soil properties for better root system. Solaiman et al. (2010) reported that biochar amended soil has high nutrient uptake.

Table 1: Effect of rice straw and husk biochar on the leaf area at different growing periods.

\begin{tabular}{ccccc}
\hline \multirow{2}{*}{ Treatments } & \multicolumn{4}{c}{ Leaf area $\left(\mathrm{cm}^{2}\right)$ per plant } \\
\cline { 2 - 5 } & 15 DAP & 30 DAP & 45 DAP & 60 DAP \\
\hline T1 & $3.09 \pm 0.26$ & $25.72 \pm 2.83$ & $110.15 \pm 5.01 \mathrm{ab}$ & $122.73 \pm 6.18 \mathrm{c}$ \\
T2 & $3.23 \pm 0.15$ & $31.16 \pm 1.69$ & $110.48 \pm 2.14 \mathrm{ab}$ & $157.20 \pm 7.26 \mathrm{~b}$ \\
T3 & $2.74 \pm 0.56$ & $31.28 \pm 3.53$ & $112.31 \pm 3.73 \mathrm{ab}$ & $174.57 \pm 2.38 \mathrm{a}$ \\
T4 & $2.83 \pm 0.78$ & $27.84 \pm 5.90$ & $106.50 \pm 4.95 \mathrm{~b}$ & $159.68 \pm 6.96 \mathrm{~b}$ \\
T5 & $2.71 \pm 0.23$ & $30.54 \pm 3.01$ & $110.43 \pm 1.36 \mathrm{ab}$ & $164.37 \pm 5.65 \mathrm{ab}$ \\
T6 & $3.19 \pm 1.38$ & $40.95 \pm 0.38$ & $124.03 \pm 7.87 \mathrm{a}$ & $185.93 \pm 5.45 \mathrm{a}$ \\
\hline F test & $\mathrm{ns}$ & $\mathrm{ns}$ & $*$ & $*$ \\
CV\% & 33.9 & 18.8 & 7.4 & 9.9 \\
\hline
\end{tabular}

Mean with the same letter in each column are not significantly different at $5 \%$ level using Tukey's test. F test: ns- non significant, *-significant.

Table 2: Effect of rice straw and husk biochar on tiller numbers at different growing periods.

\begin{tabular}{cccc}
\hline \multirow{2}{*}{ Treatments } & \multicolumn{3}{c}{ Number of tillers per hill } \\
\cline { 2 - 4 } & 30 DAP & 45 DAP & 60 DAP \\
\hline T1 & $0.00 \pm 0.00$ & $2.50 \pm 0.41 \mathrm{~b}$ & $2.83 \pm 0.81 \mathrm{c}$ \\
T2 & $0.50 \pm 0.29$ & $2.60 \pm 0.33 \mathrm{~b}$ & $3.00 \pm 0.33 \mathrm{bc}$ \\
T3 & $0.30 \pm 0.33$ & $3.17 \pm 0.76 \mathrm{ab}$ & $3.67 \pm 0.33 \mathrm{ab}$ \\
T4 & $0.17 \pm 1.20$ & $2.67 \pm 0.44 \mathrm{~b}$ & $3.33 \pm 0.20 \mathrm{~b}$ \\
T5 & $0.17 \pm 0.44$ & $2.67 \pm 0.39 \mathrm{~b}$ & $3.33 \pm 0.60 \mathrm{~b}$ \\
T6 & $0.10 \pm 2.33$ & $3.67 \pm 0.49 \mathrm{a}$ & $4.00 \pm 0.51 \mathrm{a}$ \\
\hline F test & $\mathrm{ns}$ & $*$ & $*$ \\
CV\% & 17.2 & 16.2 & 15.6 \\
\hline
\end{tabular}

Mean with the same letter in each column are not significantly different at 5\% level using Tukey's test. F test: ns- non significant, *-significant.

\section{Length of roots}

Table 4 shows the root lengths of rice plant during the growing periods from 15 DAP to 60 DAP in each treatment. There were no considerable variations $(\mathrm{P}>0.05)$ in longest root length at the different growing periods except at 30 DAP. Agusalim et al. (2010) mentioned that rice husk biochar enhances plant growth by improving the soil properties. 
Table 3: Effect of rice straw and husk biochar on number of roots per plant at different growing periods.

\begin{tabular}{ccccc}
\hline \multirow{2}{*}{ Treatments } & \multicolumn{4}{c}{ Number of roots per plant } \\
\cline { 2 - 5 } & 15 DAP & 30 DAP & 45 DAP & 60 DAP \\
\hline T1 & $7.33 \pm 1.88$ & $18.33 \pm 1.48 \mathrm{~b}$ & $44.33 \pm 1.45 \mathrm{bc}$ & $85.83 \pm 0.60 \mathrm{~b}$ \\
T2 & $6.33 \pm 0.60$ & $21.83 \pm 0.73 \mathrm{ab}$ & $47.00 \pm 1.44 \mathrm{ab}$ & $89.17 \pm 0.92 \mathrm{~b}$ \\
T3 & $5.66 \pm 0.17$ & $22.83 \pm 2.46 \mathrm{ab}$ & $56.00 \pm 2.02 \mathrm{ab}$ & $97.17 \pm 1.45 \mathrm{ab}$ \\
T4 & $5.00 \pm 0.76$ & $19.00 \pm 0.76 \mathrm{ab}$ & $53.33 \pm 1.01 \mathrm{ab}$ & $98.67 \pm 0.83 \mathrm{ab}$ \\
T5 & $5.83 \pm 1.33$ & $19.16 \pm 0.73 \mathrm{ab}$ & $56.67 \pm 1.20 \mathrm{ab}$ & $97.67 \pm 1.36 \mathrm{ab}$ \\
T6 & $8.66 \pm 0.17$ & $23.16 \pm 0.17 \mathrm{a}$ & $59.67 \pm 1.30 \mathrm{a}$ & $105.33 \pm 0.3 \mathrm{a}$ \\
\hline F test & $\mathrm{ns}$ & $*$ & $*$ & $*$ \\
CV\% & 17.9 & 7.9 & 5.7 & 3.3 \\
\hline
\end{tabular}

Mean with the same letter in each column are not significantly different at 5\% level using Tukey's test. F test: ns- non significant, *-significant.

Table 4: Effect of rice straw and husk biochar on root length of rice plant at different growing periods.

\begin{tabular}{cclcc}
\hline \multirow{2}{*}{ Treatments } & \multicolumn{4}{c}{ length of longest roots $(\mathrm{cm})$} \\
\cline { 2 - 5 } & 15 DAP & 30 DAP & 45 DAP & 60 DAP \\
\hline T1 & $3.66 \pm 0.44$ & $6.66 \pm 0.92 \mathrm{ab}$ & $9.53 \pm 0.32$ & $9.43 \pm 0.39$ \\
T2 & $3.53 \pm 0.15$ & $5.58 \pm 0.68 \mathrm{~b}$ & $9.78 \pm 0.06$ & $9.65 \pm 0.26$ \\
T3 & $3.75 \pm 0.20$ & $6.83 \pm 0.33 \mathrm{ab}$ & $9.63 \pm 0.24$ & $9.53 \pm 0.15$ \\
T4 & $3.36 \pm 0.34$ & $5.83 \pm 0.60 \mathrm{~b}$ & $9.66 \pm 0.33$ & $9.51 \pm 0.29$ \\
T5 & $3.16 \pm 0.44$ & $7.16 \pm 0.33 \mathrm{ab}$ & $9.38 \pm 0.17$ & $9.33 \pm 0.38$ \\
T6 & $4.25 \pm 0.31$ & $8.33 \pm 0.44 \mathrm{a}$ & $10.01 \pm 0.16$ & $9.97 \pm 0.30$ \\
\hline F test & $\mathrm{ns}$ & $*$ & $\mathrm{~ns}$ & $\mathrm{~ns}$ \\
CV\% & 14.2 & 15.5 & 4.4 & 5.9 \\
\hline
\end{tabular}

Mean with the same letter in each column are not significantly different at $5 \%$ level using Tukey's test. F test: ns- non significant, *-significant.

\section{Dry weight of shoots}

The dry weights of shoots during the growing period from 15 to 60 DAP are presented in Table 5. There were no significant differences in dry weights of shoots at 15, 30 and 45 DAP.Significant difference was noted between the treatments at 60 DAP and T6 had high value of leaf area and dry weight of shoot. Khan and Khalil (2010) stated that leaf area determines dry matter production of crops.

\section{Dry weight of roots}

The dry weight of roots were recorded during the growing period from 15 to 60 DAP as given in Table 6. No significant variations $(\mathrm{P}>0.05)$ were observed in dry weights of roots at 15 DAP to 45 DAP. But at $60 \mathrm{DAP}$, there was remarkable difference among treatments. T6 had higher dry weight of roots among the treatments. Organic materials added to soil may increase soil properties for better root system. 
Table 5: Effect of rice straw and husk biochar on dry weight of shoots at different growing periods.

\begin{tabular}{ccccc}
\hline \multirow{2}{*}{ Treatments } & \multicolumn{4}{c}{ Dry weight of shoots } \\
\cline { 2 - 5 } & 15 DAP & 30 DAP & 45 DAP & 60 DAP \\
\hline T1 & $0.02 \pm 0.00$ & $0.43 \pm 0.12$ & $1.55 \pm 0.54$ & $3.37 \pm 0.12 \mathrm{c}$ \\
T2 & $0.02 \pm 0.00$ & $0.25 \pm 0.09$ & $1.55 \pm 0.23$ & $3.98 \pm 0.25 \mathrm{bc}$ \\
T3 & $0.02 \pm 0.00$ & $0.55 \pm 0.04$ & $1.70 \pm 0.44$ & $4.91 \pm 0.39 \mathrm{ab}$ \\
T4 & $0.02 \pm 0.00$ & $0.32 \pm 0.02$ & $1.64 \pm 0.52$ & $4.15 \pm 0.08 \mathrm{bc}$ \\
T5 & $0.02 \pm 0.00$ & $0.52 \pm 0.11$ & $1.52 \pm 0.24$ & $4.41 \pm 0.29 \mathrm{ab}$ \\
T6 & $0.03 \pm 0.00$ & $0.51 \pm 0.05$ & $1.89 \pm 0.29$ & $5.15 \pm 0.32 \mathrm{a}$ \\
\hline F test & $\mathrm{ns}$ & $\mathrm{ns}$ & $\mathrm{ns}$ & $*$ \\
CV\% & 23.1 & 17.2 & 13.8 & 11.4 \\
\hline
\end{tabular}

Mean with the same letter in each column are not significantly different at 5\% level using Tukey's test. F test: ns- non significant, *-significant.

Table 6: Effect of rice straw and husk biochar on dry weight of roots at different growing periods.

\begin{tabular}{ccccc}
\hline \multirow{2}{*}{ Treatments } & \multicolumn{4}{c}{ Dry weight of roots } \\
\cline { 2 - 5 } & 15 DAP & 30 DAP & 45 DAP & 60 DAP \\
\hline T1 & $0.024 \pm 0.01$ & $0.107 \pm 0.03$ & $0.78 \pm 0.33$ & $2.96 \pm 0.37 \mathrm{bc}$ \\
T2 & $0.018 \pm 0.00$ & $0.049 \pm 0.01$ & $0.35 \pm 0.10$ & $3.41 \pm 0.21 \mathrm{c}$ \\
T3 & $0.023 \pm 0.00$ & $0.095 \pm 0.02$ & $0.55 \pm 0.14$ & $3.97 \pm 0.12 \mathrm{ab}$ \\
T4 & $0.011 \pm 0.00$ & $0.102 \pm 0.00$ & $0.82 \pm 0.23$ & $3.59 \pm 0.17 \mathrm{~b}$ \\
T5 & $0.019 \pm 0.00$ & $0.090 \pm 0.01$ & $0.93 \pm 0.34$ & $3.84 \pm 0.20 \mathrm{ab}$ \\
T6 & $0.013 \pm 0.00$ & $0.149 \pm 0.05$ & $1.24 \pm 0.58$ & $4.27 \pm 0.40 \mathrm{a}$ \\
\hline F test & $\mathrm{ns}$ & $\mathrm{ns}$ & $\mathrm{ns}$ & $*$ \\
CV\% & 58.7 & 50.2 & 76.3 & 13.6 \\
\hline
\end{tabular}

Mean with the same letter in each column are not significantly different at 5\% level using Tukey's test. F test: ns- non significant, *-significant.

\section{Yield attributes}

The results revealed that number of spikelets per panicle and number of empty grains per panicle were not shown any significant variations $(\mathrm{P}>0.05)$ among the treatments (Table 7) but total number of grains per panicle showed considerable difference among them. T1 and T2 varied significantly $(\mathrm{P}<0.05)$ in total number of filled grains per panicle with other treatments and T6 had high value among the treatments. The lowest number of filled grain per panicle was recorded in $\mathrm{T} 1$ treatment without rice straw and husk biochar incorporation.

The result revealed that the total weight of filled grains per panicle was significantly $(\mathrm{P}<0.05)$ varied among the treatments (Table 8 ). Hundred seed weight was showed no remarkable difference among them. No significant difference $(\mathrm{P}>0.05)$ was observed in total weight of filled grains per panicle between $\mathrm{T} 1$ and $\mathrm{T} 2$. T6 had high 
grain weight per panicle among the treatments. Zhang et al. (2010) and Shackley et al. (2012) reported that rice husk biochar increased rice yield. The 1000 grain weight was higher in composted rice straw with NPK fertilized plants than that of composted rice straw (Son et al., 2013). In present study, the numbers of tillers, number of filled grains per panicle, grain weight per panicle and hundred grain weight increased in rice straw and husk biochar treated soil. Asaduzzaman and Pramanik (2005) reported that the grain yield increased by about $5 \%$ over control for addition of $10 \mathrm{t} / \mathrm{ha}$ rice straw.

Table 7: Effect of rice straw and husk biochar on numbers of spikelets per panicle and grains per panicle in each treatment.

\begin{tabular}{ccccc}
\hline Treatments & $\begin{array}{c}\text { Number of } \\
\text { spikelets per } \\
\text { panicle }\end{array}$ & $\begin{array}{c}\text { Total number of } \\
\text { grains per panicle }\end{array}$ & $\begin{array}{c}\text { Number of } \\
\text { empty grains } \\
\text { per panicle }\end{array}$ & $\begin{array}{c}\text { Total number of } \\
\text { filled grains per } \\
\text { panicle }\end{array}$ \\
\hline T1 & 11.67 & $169.33 \mathrm{c}$ & 13.00 & $156.67 \mathrm{c}$ \\
T2 & 10.67 & $173.33 \mathrm{c}$ & 15.00 & $158.33 \mathrm{c}$ \\
$\mathrm{T} 3$ & 11.33 & $184.33 \mathrm{ab}$ & 16.33 & $168.00 \mathrm{ab}$ \\
T4 & 11.00 & $179.00 \mathrm{~b}$ & 15.67 & $163.33 \mathrm{~b}$ \\
T5 & 11.00 & $181.67 \mathrm{ab}$ & 16.00 & $165.67 \mathrm{ab}$ \\
T6 & 12.00 & $187.67 \mathrm{a}$ & 15.33 & $170.33 \mathrm{a}$ \\
\hline F test & $\mathrm{ns}$ & $*$ & $\mathrm{~ns}$ & $*$ \\
CV \% & 8.2 & 2.9 & 10.6 & 3.1 \\
\hline \multicolumn{7}{l}{ Mean with the same letter in each column are not significantly different at 5\% level using } \\
Tukey’s test. F test: ns- non significant, *-significant.
\end{tabular}

Table 8: Effect of rice straw and husk biochar on grain weight of rice.

\begin{tabular}{ccc}
\hline Treatments & $\begin{array}{c}\text { Total weight of } \\
\text { filled grains per } \\
\text { panicle }(\mathrm{g})\end{array}$ & $\begin{array}{c}\text { Weight of } 100 \\
\text { seeds }(\mathrm{g})\end{array}$ \\
\hline $\mathrm{T} 1$ & $2.870 \mathrm{c}$ & 1.831 \\
$\mathrm{~T} 2$ & $2.901 \mathrm{c}$ & 1.833 \\
$\mathrm{~T} 3$ & $3.116 \mathrm{ab}$ & 1.854 \\
$\mathrm{~T} 4$ & $3.011 \mathrm{bc}$ & 1.843 \\
$\mathrm{~T} 5$ & $3.057 \mathrm{~b}$ & 1.845 \\
$\mathrm{~T} 6$ & $3.142 \mathrm{a}$ & 1.846 \\
\hline F test & $*$ & $\mathrm{~ns}$ \\
CV \% & 4.8 & 4.8 \\
\hline Mean with the same letter in each column are not \\
significantly different at 5\% level using Duncan's test. F \\
test: *-significant.
\end{tabular}




\section{CONCLUSION}

Rice straw and paddy husk are abundant in rice producing area and it can be used to improve soil properties in rice field. In this experiment, addition of rice straw and hush biochar showed better crop performance during their growing periods. The results revealed that rather than applying chemical fertilizer alone, incorporation of rice straw (1.0 t/ha) and husk biochar (1.0 t/ha) along with chemical fertilizer is possible to increase the grain weight per panicle for better yield under local conditions.

\section{REFERENCES}

Agusalim, M., Utomo, W.H. and Syechfani, M.S. 2010. Rice husk biochar for rice based cropping system in acid soil 1 . The characteristics of rice husk biochar and its influence on the properties of acid sulfate soils and rice growth in West Kalimantan, Indonesia. Journal of Agricultural Science, 2(1): 39-47.

Asaduzzaman, M. and Pramanik, M. H. R. 2005. Intoxication of added rice straws in soil on the growth and yield of transplant aman rice. Journal of Bangladesh Society for Agricultural Science and Technology, 2(3\&4): 9-12.

Gamage, A., Basnayake, B., Costa, J and Manel, E. 2012. Impact of rice husk charcoal application soil prosperities and growth and yield of rice. In: Proceeding of International Forestry and Environment Symposium of the Department of Forestry and Environmental Science, University of Sri Jayewardenepura, Sri Lanka. Session IV: Natural Resource Management, 72 pp. Gaskin, J.W., Speir, R.A., Harris, K., Das, K.C., Lee, R.D., Morris, L.A. and Fisher, D.S. 2010. Effect of Peanut Hull and Pine Chip Biochar on Soil Nutrients, Corn Nutrient Status, and Yield. Agronomy Journal, 102 (2): 623-33.

Kessler, J.R., 2011. (2010, September 10). Greenhouse potting media. Accessed,http://www.ag.auburn.edu/hort/l andscape/pottingmedia.htm.
Khan, A. and Khalil, S.K. 2010. Effect of leaf area on dry matter production in aerated mung bean seed. International Journal of Plant Physiology and Biochemistry, 2(4): 52-61.

Milla, O.V., Rivera, E.B., Huang, W.J., Chien, C.C. and Wang, Y.M. 2013. Agronomic properties and characterization of rice husk and wood biochars and their effect on the growth of water spinach in a field test. Journal of Soil Science and Plant Nutrition, 13 (2): 251-266.

Oladipo, O.G., Olayinka, A. and Aduayi, E.A. 2005. Effects of organic amendments on microbial activity, $\mathrm{N}$ and $\mathrm{P}$ mineralization in an Alfisol. Environment Management Journal, 2: 30-40.

Shackley, S., Carter, S., Knowles, T., Middelink, E., Haefele, S. and Haszeldine, S. 2012. Sustainable gasification-biochar Systems? A case-study of rice husk gasification in Cambodia, Part II: Field trial results, carbon abatement, economic assessment and conclusions. Energy Policy, 41: 618-623.

Solaiman, Z.M, Blackwell, P., Abbott, L.K. and Storer, P. 2010. Direct and residual effect of biochar application on mycorrhizal root colonisation, growth and nutrition of wheat. Australian Journal of Soil Research 48: 546-554.

Somaratne, W.G. 2010. The System of Rice Intensification (SRI) and food security among the poor: Opportunities and Constraints. In: Proceedings of the National Conference on Water, Food Security and Climate Change in Sri Lanka [Weligamage, P., Godaliyadda, G.G.A. and Jinapala, K. (Eds.)] Vol. 1: Irrigation for food security. Colombo, Sri Lanka held during 9-11 June 2009. International Water Management Institute. 81-91 pp. doi:10.3910/2010.210.

Son, T.T.N., Thu, T.T.A., Nam, N.N. and Man, L.H. 2013. Influence of rice straw treated by indigenous Trichoderma spp. on soil fertility, rice grain yield and economic efficiency in the mekong delta. Omonrice 19: 145-152. 
Zhang, A., Cui, L., Pan, G., Li, L., Hussain, Q., Zhang, X., Zheng, J. and Crowley, D. 2010. Effect of biochar amendment on yield and methane and nitrous oxide emissions from a rice paddy from Tai Lake plain, China. Agriculture, Ecosystems and Environment, 139: 469-475. 